\title{
A way to increase pupils' motivation in their English lessons? : A teaching experiment in a small group receiving adapted education
}

Heidi Kristin Reppen ${ }^{\mathrm{a}}$

a Vennesla videregående skole

\section{Introduction}

The topic of this paper, how to increase pupils' motivation in their English lessons, was "born" quite early into my practice as a teacher in English at an upper secondary school. As a new teacher, working with different classes, it struck me that every class or group has its own "feel". What I quickly registered in a small group needing adapted education in English, was that the motivation for learning English was low. In this paper, therefore, I will focus on the theme of motivation, and I will use a teaching experiment and pupils' answers on a questionnaire as the source of data.

The hypotheses ${ }^{1}$ that will be my guidance throughout this paper, and later will be referred to under the headings "mastery" "variation" and "involvement" can be summed up as follows:

- Hypothesis 1: Lessons with short and concrete tasks that the pupils actually are able to master will enhance their motivation.

\footnotetext{
${ }^{1}$ As I will explain further under the heading "Methods and limitations", the design of this study does not really lend itself to proper testing of hypotheses. It is therefore appropriate to present these hypotheses as guidance for the discussions and the reflections in the paper, nothing more.
} 
- Hypothesis 2: More varied lessons will enhance the pupils' motivation.

- Hypothesis 3: Involving the pupils in discussions of their motivation, their work, their challenges and their progress will enhance their motivation.

In section 2, I will present various thoughts and theories on motivation. In section 3, I will write about the group of pupils and the methods for data collection. In sections 4 and 5,1 will present the findings in the study and discuss them. The paper will end with my conclusions in section 6 . 


\section{Motivation}

\section{What is motivation?}

Motivation has been the subject of many investigations and theories. Although it is possible to learn something without being highly motivated, or vice versa, to be highly motivated without learning much (Ogden 2008), motivation is widely regarded as a success criterion when it comes to the process of learning. Jeremy Harmer, a teacher trainer and author of several books on teaching English as a foreign language, puts it this way: "... we have to want to do something to succeed at it" (2012: 98).

According to Harmer, motivation is "some kind of internal drive which pushes someone to do things in order to achieve something" (2012: 98). As is obvious from the last part of this definition, motivation as a term is highly associated with the concept of reaching some kind of goal.

Motivation is commonly split into different types, internal and external motivation ${ }^{2}$. Jim Scrivener, who has worked on many teacher training courses as well as written books on teaching English as a foreign language, thinks of external motivation as what takes place when there are external reasons as to why somebody wants to learn or study, for instance to pass an exam or to enter university. The term internal motivation, however, is appropriate when somebody wants to learn or study just for rewards within the work itself (Scrivener 2011).

Some, among others Drew and Sørheim (2009), think internal motivation and external motivation may go hand in hand. The distinction between the two terms internal and external motivation, or indeed, whether there exists a clear distinction between these two forms at all, are not the subject of this paper.

\footnotetext{
${ }^{2}$ Other terms in common use are intrinsic and extrinsic motivation.
} 


\section{What fosters motivation?}

\section{Mastery}

Many theorists, both within the general fields of pedagogic and didactic literature and within the field of teaching English as a foreign language, consider the ability to master a task as highly related to motivation. Although there is some uncertainty regarding whether motivation leads to mastery, or mastery leads to motivation (Drew and Sørheim 2009), mastery will be looked upon as a prerequisite for motivation in this paper.

In Harmer's outline of what he calls "The motivation angel", he stresses five aspects in the building of motivation. One of these is mastery, or as he calls it, achievement. "Nothing motivates like success. Nothing demotivates like continual failure" (2012: 101). Although Harmer also states that there must be some challenge to a task in order to make it feel like an achievement, one might argue that the degree of challenge introduced in a lesson should depend on the type of pupils in a particular class.

Another source of support for the view that mastery is an important feature in motivation can be found in the psychologist Albert Bandura's socio-cognitive theory, which includes his thoughts on "self-efficacy". Bandura points out that each individual's belief in whether she or he will be able to do the task ${ }^{3}$, will affect his willingness to start doing a task, and persist in doing it (Bandura 1977 and 1986, quoted in Imsen 2009). According to Bandura, then, pupils will show little interest in the lesson if the tasks seem too difficult in the first place.

\section{Variation}

The focus on varied activities seems obvious today, at least at the levels below university level. This has not always been the case, and as Drew and Sørheim (2009: 12) put it: "We would not like the learners of today to be taught a foreign language in the same way as we ourselves were taught in the 50 s and $60 \mathrm{~s}^{\prime \prime}$. They continue with arguing for a balance between different methods and materials, as well as a balance between focusing on various aspects of the language, in other words: variation. They further underscore the importance of variation by referring to Crooke and Schmidt's view that "motivation can be increased if

\footnotetext{
${ }^{3}$ Bandura also stresses the individual's view on the importance of doing the task, but I will not focus on this part of his "self-efficacy"- theory here.
} 
activities are varied and introduced in such a way that learners become curious and excited about what will follow" (1991, quoted in Drew and Sørheim 2009: 21).

Harmer (2012) also stresses the importance of the choice of activities in the building of motivation by saying that learners have different styles and preferences. If we want to cater for these different styles without teaching the pupils on a one-to-one basis, variation in teaching methods seems to be an obvious strategy.

Younger and Warrington (2005), who have done research on disengaged boys in secondary schools, also point to the importance of addressing multiple intelligences and catering for kinesthetic learning ${ }^{4}$ in lessons.

\section{Involvement}

Harmer uses the term agency describing one of the aspects he sees as essential in building motivation. By using this term he thinks of how pupils can be involved in the learning process, and be "doers" instead of pupils who are the passive recipients of teaching "being done" to them: "When students have agency, they get to make some of the decisions about what is going on, and, as a consequence, they take some responsibility for their learning" (2012: 103).

The Norwegian researcher Terje Ogden (2008: 156, my translation), the author of a book on how to develop quality in schools, also underscores the importance of involvement, or agency, and in particular in involving pupils in discussions on how they work: "If we explain to pupils the link between achievement, ability and effort, they have the possibility to develop an understanding of how they can affect or control their learning environment". To help pupils gain motivation, therefore, it might be beneficial that the teacher helps them to look consciously at how they work and what learning strategies they can use.

Involving pupils in this way may well include a "mentoring" type of relationship between teacher and pupil. Younger and Warrington (2005) refer to positive results in pupils' achievement in schools where pupils have been mentored by senior members of staff in sessions where they have tried to support, set targets for and monitor pupils' learning process. Although their studies involve other mentors than the pupils' regular teacher, the

\footnotetext{
${ }^{4}$ A learning process where the pupil carry out a physical activity.
} 
results indicate support for involvement, focus on goals and raising awareness of how learning take place. As one of the pupils in a study Younger and Warrington (2005: 89) conducted put it: "Teaching is not about teachers doing things to us, but about us understanding how we learn and how we can get better at it".

Finally, then, to sum up thoughts on motivation discussed in this section: There seems to be support for focus on mastery, variation and involvement of pupils themselves as a means to enhance pupils' motivation.

\section{The data}

\section{The group of pupils}

I teach a small group of four attending vocational studies at VG1-level at an upper secondary school. The school is offering these pupils to be taught in a small group because they need adapted education, either because they have been granted a legal right to adapted education ${ }^{5}$ or because they have applied for adapted education themselves. Along with the competence aims ${ }^{6}$ that all pupils at upper secondary school need to work towards, these pupils also need more practice in all the basic skills in English: Writing, speaking, reading and listening.

In all schools with vocational studies there are quite a few pupils like these: Pupils with limited skills in and motivation for theoretical subjects such as English, Norwegian, Mathematics and Science.

\section{Method, data and limitations}

After some deliberation, I found out that I wanted to try station teaching in this group. In an article on station teaching published on the NSTA ${ }^{7}$ WebNewsDigest, the teacher Denise Jaques Jones (2007) defines it in the following manner:

\footnotetext{
${ }^{5}$ In the Norwegian system, such a legal right given to individuals is called "individuell opplæringsplan", IOP for short.

${ }^{6}$ These pupils must work towards the same competence aims in English as all other pupils at VG1- and VG2 level in upper secondary education.

${ }^{7}$ NSTA is an acronym for the National Science Teachers Association (NSTA), an organization in the USA. Its members are science teachers and others interested in science teaching.
} 
"The Station Approach is a method of instruction in which small groups of students move through a series of learning centers, or stations, allowing teachers with limited resources to differentiate instruction by incorporating students' needs, interests, and learning styles. The Station Approach supports teaching abstract concepts as well as concepts that need a great deal of repetition"

(http://www.nsta.org/publications/news/story.aspx?id=53323\&print=true).

I chose this method of teaching because I saw that it gave me the possibility to focus on all the features that I identified in section 2 and argued would foster motivation: The mastery of tasks, as I could design short and specific tasks for each station and still cover several areas of language teaching, the importance of variation which the method in itself caters for, and, finally, with a particular design of one of the stations, the involvement of pupils in a discussion on motivation, learning and strategies.

The data in this paper comes from three sources: My observation of the group at work in a teaching experiment, the pupils' answers on two questionnaires ${ }^{8}$ and my conversations with the pupils during the teaching. The nature of this small study is qualitative, both with regard to the number of cases, four pupils, and the type of data, which is mainly observation, conversations and some open-ended answers to a questionnaire ${ }^{9}$.

The pupils answered the first questionnaire at the beginning of November 2012, before any conscious effort to alter the teaching methods had been carried out. After filling in the questionnaire, we immediately had an English lesson using "stations". We had another station teaching session in early December ${ }^{10}$, and the pupils then filled in another questionnaire at the end of that session. I consider the questionnaire and discussion with the pupils as sources of data, but also as a part of the teaching experiment itself.

It is important to note that the findings in this study cannot be generalized beyond the particular group of pupils: Firstly, it is a qualitative study based on four pupils' answers and behaviour. Secondly, the time span of the study is short, which means that we know relatively little about what happened to these pupils in all the years leading up to the study, and nothing about the pupils' future in the long term. Thirdly, when one of the hypotheses is about variation, one has to take into consideration that the introduction of a new teaching

\footnotetext{
${ }^{8}$ Please see appendix for a copy of the questionnaires and some of the teaching material used in the first teaching experiment.

${ }^{9}$ The only exceptions from the overall qualitative nature of the data, are some questions in the questionnaire where the pupils are asked to rank their opinions on a scale from 1 to 5 .

${ }^{10}$ I will not go into details regarding the second session with learning stations in this paper, it is the first session that is the main focus of this paper.
} 
practice in itself will bring an element of variation into the equation - whatever the nature of that teaching practice.

The findings in this study can, however, be used for making assumptions about one's own teaching practice - a valuable part of trying to act as a "a reflective practitioner".

\section{Results}

\section{Status - the pre-experiment situation in class}

Scrivener claims that "a frequent cause of difficulties within classes is when there is a significant mismatch of motivation levels amongst the course participants..."(2011: 84). In contrast to this quote, the situation in the group that I teach was different: My pupils seemed quite unison in regarding English as something they just have to get through, like so many other of life's obstacles. When we started our lessons and they were supposed to start working, they quite often made comments such as "do we have to take out our computer?" or sometimes, "we only want to work with our computers" (as opposed to writing on paper), other expressive remarks such as "oh no", and the very popular "can we finish off class early today?" These remarks all added to the image of the pupils being generally uninterested, at least in our English classes.

The teaching I had been practising at the time consisted of fairly traditional teaching methods, such as the reading of texts from the textbook and other sources to each other. The reading would typically be followed by a session with tasks, some of them related to grammar, and I would go through them and give some feedback.

So, for some time, we had sessions such as these, where work was being done, but without detectable motivation among the pupils to work hard, and without accomplishing much in the way of actually improving their skills. I tried to find out what could make them learn some of the more "boring" aspects of language in a way that would engage them and not be too difficult. 


\section{The teaching experiment: What happens if....?}

\section{The station teaching session}

I planned two sessions with station teaching, and it is the first of these that I will refer to in this paper ${ }^{11}$. The activities included a station with a short reading activity and a list of words, followed by a station which included tasks on the particular text, as well as small test to see if they remembered the words. Another station included a short information note on the specific field of grammar, followed by another station with grammar tasks. Another set of stations included the reading of a short text in the simple present tense, followed by a station where they were supposed to write a text in the simple present tense themselves. One of the stations involved them talking with me about their answers on the questionnaire they had filled in earlier in the same lesson and what we could do in the future to make them learn more.

When we started on sessions with various stations, the pupils went ahead and did their tasks without any complaining. I had deliberately tried to make the tasks fairly easy. There was one station, on grammar, where a few of them required help, and I was able to give it to them, as I had some time available in between having my conversations with them.

\section{The questionnaire and the discussion with each pupil}

The questionnaire and discussions revealed a higher level of motivation among the pupils than I had expected. On a scale from 1 to 5 , where 1 means low motivation to learn more English and 5 means high motivation, three of the pupils answered " 4 ", whereas one of them answered " 3 ". They gave answers such as "reading and writing", "practise grammar", "read and solve tasks" and "must improve my skills on verb tenses and increase my level of motivation" when asked what they needed to work on.

We discussed their answers, and I tried to focus on their strengths and what they needed to work more on, as well as strategies they could use.

\footnotetext{
${ }^{11}$ Please see appendix for more information.
} 


\section{Status - the post-experiment situation in class: What came out of it?}

Working with station teaching in class seemed to work well, and I observed an increased level of motivation during the session, compared to the other types of lessons we had practised earlier. After another session of station teaching, I made the pupils fill in another questionnaire as a follow up. The pupils expressed a relatively positive attitude to working with stations. When asked to rank how they liked this way of teaching, three of them answered " 3 "12 and one of them answered " 4 " on a scale from 1 to 5 , where 5 is the most positive answer. All of them expressed motivation at the same level as on the former questionnaire: Three of them expressed " 4 " as their motivational level, and one of them answered " 3 " on a scale where 5 is the most positive answer.

After the teaching experiment was over with, we would easily slip back to old patterns in our ordinary lessons, the same yawning and "oh no"- expressions. When reminded of our conversation, however, the pupils would agree with the need to work on the basics and get some work done in class.

\section{Discussion of results}

To sum it all up: When taking my observations of the group at work into account, the immediate outcomes of my little teaching experiment seemed to be fairly good. The group worked well, they expressed positive attitudes to learning in our conversations and the general motivation in the weeks following the first experiment seemed to increase somewhat, if not much. When taking the pupils' answers to the second questionnaire into account, there is no obvious outcome of the second stage of the teaching experiment: Their answers did not reveal any changes in their expressed levels of motivation.

So, there are some findings that support my initial hypotheses on the importance of mastery, variation and involvement to enhance pupils' motivation, and some that do not. Based on my observations and conversations with the pupils, I would still like to argue that the experiment strengthens the hypotheses somewhat, in spite of the answers to the questionnaire: My observations indicated that the pupils worked better on basic skills work with this teaching method, compared to other types of teaching that I had practised earlier.

\footnotetext{
${ }^{12}$ One of the pupils remarked that "it was a bit hard, but quite OK, too". They actually had to work quite hard during the session, and this might explain why the activity did not score any higher when asked whether they liked this activity or not.
} 
A benefit of the station teaching method with this particular group of pupils needing to practise basic skills is that it allows for the planning of "easy" or "basic" tasks without the fear of the pupils being too bored, as they can easily move on to other tasks when they are finished. Another benefit of the method is that the variation of tasks and the pupils' awareness of the fact that they soon will attend another station, might help them stay focused and attentive on the various stations. This observation fits well with Jones' (2012) observations of the benefits of station teaching:

"By rotating students through stations that varied between quiet, mental tasks to active, verbal ones, they were kept interested and off-task behaviors were reduced. Students seemed better able to stay quiet and focused when necessary, knowing that they would move soon to a more active station. For some students, the transitions between stations gave them a quick mental break, and just by moving around the room they exhibited renewed energy and focus" (http://www.nsta.org/publications/news/story.aspx?id=53323\&print=true).

Another side of the teaching experiment that I would like to emphasize, is that the conversations I had with the pupils during the teaching experiment seemed to create some sort of engagement and conscious thinking on their behalf with regard to working harder. It might be that part of the reason for this is that these conversations gave me the possibility to show that I care about them and their progress. This line of thought is supported by Younger and Warrington (2005: 185), who state that:

“(...) In these approaches, there is a fundamental recognition that if disengaged and perhaps under-achieving boys and girls are to be more fully engaged with schooling and with learning, they need both to feel secure and valued within the school context, and to be enabled through persuasion, support and direction, to develop a sense of esteem and self-worth as learners and as people. (...) Such an approach can help students to develop a sense of agency which offers choice and confers responsibility, to identify with the schools' aims and aspirations for them as students, and thus to develop a sense of belonging and membership of school."

\section{Conclusions and implications for the classroom}

It seems that the pupils experienced some degree of mastery, variation and involvement in our station teaching session, and that this may have heightened the motivation in the group somewhat. It is probably crucial that the pupils experience mastery, variation and involvement again and again, which means that is a continual work in progress to keep them engaged and to keep their spirits up during our lessons. English learning may not be "fun" for them, or they may not express that they are very motivated, but the hope is that they 
might experience some progress after some time. A particular challenge to work more with in the future, is to involve the pupils more when it comes to their own learning process, as they are still highly dependent on being told what to do and how to do it.

The pupils in this group have probably faced defeats so many times, over the course of so many years, that it would not be realistic to turn them and their attitudes around in the course of only a month. I still hope that that a teacher's interest in them can make them feel differently about school and maybe prepare them for other learning activities later on.

The experiment and the writing of this paper have helped me scrutinize my own practice and how I work and think about my pupils. If the Norwegian education system as a whole wants to function as a system of "reflective practitioners", there should be more research into this type of pupil, as there are quite a few of them in vocational studies at the upper secondary level. These young people have finished their compulsory education with skills on a lower level than we expected and have, somewhere along the way, also lost their motivation for trying to improve their skills. How can we work along with them to make them become interested in achieving more, and at the same time, making them feel they have achieved something at the end of their education? According to Harmer, "Nothing motivates like success. Nothing demotivates like continual failure."(2012: 101) If the education system is to qualify young people for their adult life as workers, is the feeling of failure the one we want them to start out with? 


\section{References}

Drew, lon \& Sørheim, Bjørn. 2009. English Teaching Strategies. $2^{\text {nd }}$ edition. Oslo: Det Norske Samlaget.

Harmer, Jeremy. 2012. The Practice of English Language Teaching. $4^{\text {th }}$ edition, $7^{\text {th }}$ impression. Harlow: Pearson Education Limited.

Imsen, Gunn. 2005. Elevens verden. Innføring i pedagogisk psykologi. 4th edition. Oslo: Universitetsforlaget.

Jones, Denise Jaques. The Station Approach: How to Teach with Limited Resources. Article published on NSTA WebNews Digest on February 2nd 2007. Retrieved 11/18/2012 from: http://www.nsta.org/publications/news/story.aspx?id=53323\&print=true

Ogden, Terje. 2008. Kvalitetsskolen. 1st edition, 3rd impression. Oslo: Gyldendal Akademisk.

Scrivener, Jim. 2011. Learning Teaching. $3^{\text {rd }}$ edition. Oxford, Macmillan Education.

Younger, Mike and Warrington, Molly. 2005. Raising Boys Achievement in Secondary Schools. Issues, Dilemmas and Opportunities. Maidenhead: Open University Press. 


\section{Appendix}

Self-assessment questionnaire ${ }^{13}$ :

1. On a scale from 1 to 5 , where 1 means "low motivation" and 5 means "high motivation", how motivated are you for learning more English?

2. Can you think of any areas in life where you will need to use English?

3. What are you good at in English?

4. Which grade do you want to achieve in English?

5. Which grade have you achieved until now?

6. How much do you work with the subject, school lessons aside?

7. Do you know what you need to work at in order to achieve the grade you want? (Give examples - maximum 3 areas)

8. Do you know in what way you need to work to achieve the grade you want? (Be concrete)

9. A personal comment from you regarding the English lessons: "I think we should do (more of) the following so that I can learn more:"

\footnotetext{
${ }^{13}$ This questionnaire is compulsory to hand out to the pupils attending English at the school I work at. I merely added a few questions to it. This means that not all the questions in the questionnaire are relevant for this paper. The questionnaire was handed out in Norwegian, the version printed here is translated by me.
} 
Self-assessment questionnaire - a follow up ${ }^{14}$

1. On a scale from 1 to 5 , where 1 means "low motivation" and 5 means "high motivation", how motivated are you for learning more English?

2. On a scale from 1 to 5 , where 1 means "I don't like it much" and "I liked it a lot", how did you like working with stations in your English lessons?

3. Which of the following statements below do you think suits you best when considering what it is like to work with stations in your English lessons?
a) I learn just about the same in the lessons when we work with the station teaching method as in the other lessons
b) I learn less in the lessons when we work with the station teaching method, compared to other lessons
c) I learn more in lessons when we work with the station teaching method, compared to other lessons

4. Which of the statements below do you think suits best when considering your development in the subject of English?
a) I know just about as much English now as I knew when the school year started
b) I know more English now than at the time when the school year started.

5. If you have any ideas as to what we should do in our English lessons to learn more activities, books or texts we should read, etc., write them here:

\footnotetext{
${ }^{14}$ The parts of this follow-up questionnaire that I have chosen to focus on in my study are questions 1 and 2. The questionnaire was handed out in Norwegian, the version printed here is translated by me.
} 


\section{Some of the teaching material used in stations in the first teaching experiment}

1) Grammar task related to adjectives and adverbs

\section{ADJEKTIV:}

Er «hjelperen» til substantivet, som kan være et menneske, et dyr eller en ting. Det gir altså mer informasjon om dette substantivet.

Det er som regel et adjektiv hvis ordet gir svaret på disse typene spørsmål:

- Which one is it?

- What kind is it?

- How many are there?

\section{Eksempel:}

- She was kind.

- Arnie is a hard worker.

- They were happy.
BEGGE:

Er «hjelpere» i språket, som gir mer informasjon.

Det er «jobben» ordet gjør i setningen som bestemmer om det er et adjektiv eller et adverb.

Uten adjektiv og adverb som er hjelpere i språket, hadde vi fått et veldig fattig språk!

\section{ADVERB:}

Er som regel «hjelperen» til verbet, det ordet som forteller om hva som skjer / hva som blir gjort. Ender ofte, men ikke alltid, på -ly.

Det er som regel et adverb hvis ordet gir svaret på disse typene spørsmål:

- How?

- Where?

- How often?

- When?

\section{Eksempel:}

- She spoke kindly.

- Arnie works hard.

- They all laughed happily. 
Name:

1) Adjective or adverb? Write the answer and draw an arrow to the word it "helps» by giving additional information about it.

1. It was a great evening:

2. I miss him greatly:

3. They looked angrily at me:

4. This is the coldest day ever!

5. He was the first person to enter the room.

6. We waited long.

7. We were in for a long wait.

8. You sing well. 
2) Grammar task related to the use of the simple present and the present continuous

The simple present and the present continuous

The simple present: He works hard. She always watches TV.- Har med noe som gjentar seg / skjer ofte å gjøre. Se etter ord som "always" eller "usually".

The present continuous: She's doing her homework right now. Tomorrow we're going to the cinema. - Brukes om det som skjer akkurat nå (se etter ord som right now, f.eks.) eller om noe som skjer i nær framtid.

1. Who that terrible noise? (to make)

2. I usually early. (to get up)

3. They always hard.

(to work)

4. It outside.

(to snow)

5. Peter a bath right now. (to have a bath) 
3) Reading and writing task related to the simple present tense

Read this text in the simple present tense (presens / nåtid).

Notice the way it's written - afterwards, you are going to write a text in the present tense!

\section{Lupita's Day}

Hello. My name is Lupita Gonzalez. I work in a large company in Monterrey, Mexico. We make bottles and cans for soft drinks. I am a secretary. I answer the telephone and take messages. I also use a fax machine and a computer. My first language is Spanish but sometimes I speak English. Many of our clients are from the United States. My supervisor is Mr. Torres. He is an engineer. I start work at 8:00. I usually drive to work. I have lunch from 1:00 to 2:00. I finish work at 5:30. I go home and help my mother prepare dinner. We have dinner at 9:00. After dinner I usually watch television a while. I usually go to bed at 11:00.

Source: http://tx.english-ch.com/teacher/mike/level-c/lupitas-day/

Now write about your day and the way things are done at school, the way it usually is, by writing in the simple present tense! Write at least 7 sentences! 